\title{
ST-segment elevation myocardial infarction with anomalous right coronary artery originating from the mid-left anterior descending artery
}

\author{
Ozan Mehmet Demir, Masood Khan
}

Department of Cardiology, Watford General Hospital, Watford, Hertfordshire, UK

\section{Correspondence to} Dr Ozan Mehmet Demir, ozanmdemir@gmail.com

Accepted 30 July 2015
CrossMark

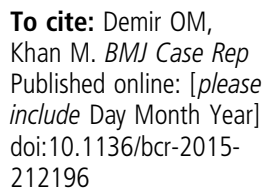

\section{DESCRIPTION}

An elderly man presented after a collapse with inferior ST-segment elevation. Coronary angiography revealed ectatic left anterior descending (LAD) artery with an aberrant side branch originating from the mid-segment (figure 1A, B). There was slow flow in this vessel and the distal segment of vessel was not visualised. There was obstructive disease in the first obtuse marginal branch of the left circumflex (LCx) artery (figure 1C). Despite searching in all three coronary sinuses and performing an aortogram the right coronary artery (RCA) was unidentified.

He subsequently had CT coronary angiography (CTCA), which revealed that the branch originating from the mid-LAD was the RCA (figure 2A). He underwent repeat angiography, contrast was injected deep into the RCA using a microcatheter, which demonstrated a chronic total occlusion of the distal RCA (figure 2B, C). The disease in the LCx artery was felt to be the reason for his acute presentation and he had successful intervention with drug-eluting stents (figure 2D).

The anomalous origin of the RCA as a branch of the LAD artery is a very rare variation of single coronary artery. The incidence of coronary artery anomalies is $1.3 \%$, RCA originating from the mid-LAD is one of the rarest anomalous coronary variation. ${ }^{12}$ Most coronary artery anomalies are incidentally found during coronary angiography, this is limited by difficult spatial orientation of X-ray. CTCA can be utilised to demonstrate origin and course of anomalous arteries. This case

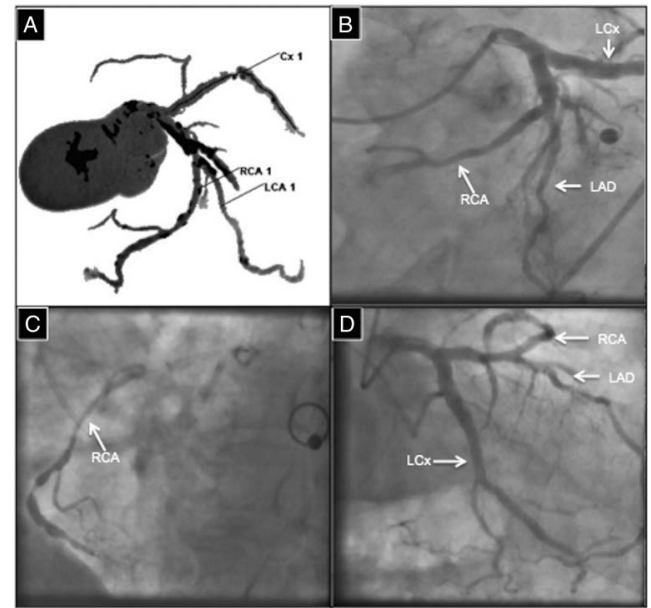

Figure 2 (A) CT coronary angiography reconstruction demonstrating anomalous origin of the right coronary artery from the mid-segment of the left anterior descending artery. (B) Left anterior oblique (LAO) caudal view demonstrating course of the anomalous right coronary artery. (C) LAO view of Finecross microcatheter in the mid and distal segments of the anomalous right coronary artery demonstrating severe obstructive mid-segment stenosis and chronic total obstruction of the distal segment. (D) Right anterior oblique demonstrating successful angioplasty with his left circumflex artery. The anomalous right coronary artery can be visualised arching over the left anterior descending artery.

highlights the importance of recognition of anatomical variation, especially in acute presentations, and demonstrates the role of CTCA.

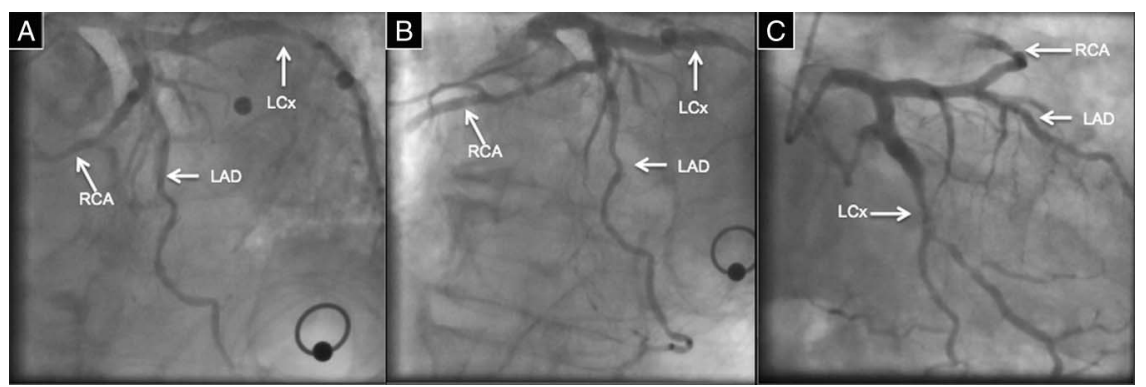

Figure 1 (A) Left anterior oblique (LAO) view demonstrating left anterior descending artery with large calibre side branch originating from the mid-segment which had an aberrant course with mid-segment stenosis. (B) LAO caudal view demonstrating course of the anomalous right coronary artery. (C) Right anterior oblique demonstrating obstructive disease in his left circumflex artery, prior to the first obtuse marginal. 


\section{Learning points}

- The incidence of anomalous origin of the coronary arteries is $1.3 \%$. Knowledge on the most common variations is essential for cardiologists.

- In patients presenting with myocardial infarction, especially with ST-segment elevation, rapid recognition of anatomical variations can be critical. Right coronary artery originating from the mid-left anterior descending artery is a very rare variation of single coronary artery.

- CT coronary angiography can be utilised to demonstrate the origin and course of anomalous arteries. Although this is usually reserved for stable patients it can be utilised in acute cases were recognition of anomalous vessels is not possible.
Competing interests None declared.

Patient consent Obtained.

Provenance and peer review Not commissioned; externally peer reviewed.

\section{REFERENCES}

1 Yamanaka 0, Hobbs RE. Coronary artery anomalies in 126,595 patients undergoing coronary arteriography Cathet Cardiovasc Diagn 1990;21:28-40.

2 Zhu J, Xiong W, Xuguang Q. A single coronary artery anomaly: right coronary artery originating from the mid left anterior descending artery J Invasive Cardiol 2011;23:258-60.

Copyright 2015 BMJ Publishing Group. All rights reserved. For permission to reuse any of this content visit http://group.bmj.com/group/rights-licensing/permissions.

BMJ Case Report Fellows may re-use this article for personal use and teaching without any further permission.

Become a Fellow of BMJ Case Reports today and you can:

- Submit as many cases as you like

- Enjoy fast sympathetic peer review and rapid publication of accepted articles

- Access all the published articles

- Re-use any of the published material for personal use and teaching without further permission

For information on Institutional Fellowships contact consortiasales@bmjgroup.com

Visit casereports.bmj.com for more articles like this and to become a Fellow 